\title{
Effects of climatic conditions on a polycrystalline photovoltaic module in Niger
}

\author{
Fatou NDIAYE ${ }^{1}$, Moustapha SENE ${ }^{2}$, Modou BEYE ${ }^{3}$, \\ Amadou S. H. MAIGA \\ Laboratoire d'Electronique, Informatique, Télécommunications et Energies Renouvelables \\ Université Gaston Berger \\ BP 234 Route de Ngalèlle, Saint-Louis, Sénégal \\ E-mail address: ${ }^{1,2,3}$ ndiayefa64@yahoo.fr, mstsene@yahoo.fr, \\ almodu@yahoo.fr, asmaiga@yahoo.com
}

Keywords: Polycrytalline Photovoltaic Module, Climatic Condition

\begin{abstract}
The main purpose of this paper is to evaluate the efficiency of a photovoltaic module operating in a sahelian country like Niger. A brief introduction to the behavior and the functioning of a photovoltaic module has been presented and the basic equations needed for a modeling based on ambient parameters have been also written. For the validation, characteristics of experimental purpose are presented with a satisfactory reliability degree. The effects of external parameters, mainly temperature, solar irradiance and wind speed have been considered on the output current characteristic and the output power characteristic. Due to their critical effects on the operation of the panel, effects of series resistances were also studied.
\end{abstract}

\section{INTRODUCTION}

Photovoltaic (PV) cells convert solar energy directly into electricity that can be used for many purposes. This technology is considered in many countries as an interesting alternative to fossil fuels. It can generate electricity with no $\mathrm{CO}_{2}$ emissions and requires almost no maintenance. This sustainable source of energy has achieved tremendous growth in recent years and it is considered as the most promising renewable energy technology. However, the power delivered by a photovoltaic panel is highly dependent on climatic conditions: temperature, solar irradiation, wind speed, humidity, etc. [1-4].

Knowledge of the characteristic of a PV panel is a pre-requisite for modeling PV power supply. The power delivered by a PV module varies with the environment. The objective of this study is to estimate a simple model of current and power panel based on climatic parameters such as ambient temperature, solar irradiation and wind speed, and to analyze their effects on the efficiency of the module.

\section{MATHEMATICAL MODEL OF A SOLAR CELL}

The solar power is generated by direct conversion of the sunlight with a photovoltaic cell. Several cells are connected to each other in series and / or in parallel to form a solar panel $[5,6]$.

An association of identical number of cells (ns) in series increases the voltage of the panel and all cells are traversed by the same current.

Similarly, if the cells are associated in parallel, the current increases and the voltage at the terminals of each cell is the same.

The electrical characteristic of the current $I=f(V)$ of a photovoltaic cell can be schematically represented as shown in Fig. 1. [7-9]: 


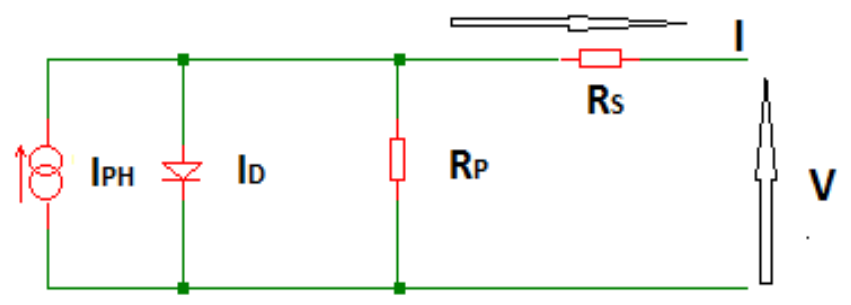

Fig. 1. Solar cell model

This circuit is composed of:

- A current source IPH generated by light in the cell;

- A diode representing the PN junction in the cell and characterized by a current ID ;

- A series resistor RS which is the internal resistance of the cell, and which depends mainly on the semiconductor material used and the contact resistance of grids;

- A parallel resistor RP due to the leakage current through the junction.

Applying Kirchhoff's law, the current delivered by the cell is equal to:

$$
\begin{aligned}
& I=I_{P L}-I_{D}-\frac{\left(V+I * R_{S}\right)}{R_{D}} \\
& I=I_{P L}-I_{0} * e^{\left(\frac{V D}{F T}-1\right)}-\frac{\left(V+I * R_{S}\right)}{R_{U}} \\
& V_{D}=V+R_{S} * I \\
& V_{T}=\frac{\left(n * k * T * N_{S}\right)}{q}
\end{aligned}
$$

$\mathrm{V}_{\mathrm{D}}$ : voltage of the diode,

$\mathrm{I}_{0}$ : reverse saturation current of the diode,

$\mathrm{V}_{\mathrm{T}}$ : the thermal voltage

$\mathrm{n}:$ the ideality factor,

$\mathrm{k}$ : Boltzmann's constant, q: electron charge,

$\mathrm{T}:$ temperature of the cell

$\mathrm{N}_{\mathrm{S}}$ : number of associated cell in series.

The short-circuit current, representing the current for which the voltage across the cell is zero, can be obtained:

$$
\begin{aligned}
& I_{C C}=I_{P H}-e^{\frac{\left(B_{g} v_{C G C}\right)}{W_{T}}}-\frac{I_{C C} * R_{S}}{R_{p}} \\
& I_{c e} \cong \frac{I_{P E}}{1+\frac{E_{S}^{*}}{R_{P}}}
\end{aligned}
$$




$$
I_{P L}=\left[I_{C \odot Q}+K_{1}\left(T-T_{r q f}\right)\right] \cdot\left(\frac{\psi}{\psi_{r e f}}\right)
$$

where $\mathrm{I}_{\mathrm{CC} 0}(\mathrm{~A})$ is the short-circuit current for a standard solarirradiation $\Psi$ ref $\left(\mathrm{W} / \mathrm{m}^{2}\right)$ and at the reference temperature Tref, $\mathrm{K}\left(\% /{ }^{\circ} \mathrm{C}\right)$ is the temperature coefficient of the cell and $\Psi$ $\left(\mathrm{W} / \mathrm{m}^{2}\right)$ the solar irradiation.

The saturation current of the diode depends strongly on the temperature and can be expressed as shown in Equation:

$$
I_{0}=I_{0 \mathrm{n}} *\left(\frac{T}{T_{r e f}}\right)^{2} * \exp \left[\frac{E_{G} * q}{k} *\left(\frac{1}{T_{r e f}}-\frac{1}{T}\right)\right]
$$

$\mathrm{E}_{\mathrm{G}}$ is the band gap energy of the semiconductor and $\mathrm{I} 0 \mathrm{n}$ the saturation current defined as:

$$
I_{\text {On }}=\frac{I_{C C O}}{\exp \left(\frac{V_{C O \mathrm{n}}+K_{2} *\left(T-T_{\text {ref }}\right)}{V_{T}}\right)-1}
$$

$\mathrm{K} 2\left(\mathrm{mV} /{ }^{\circ} \mathrm{C}\right)$ is the temperature coefficient of the open-circuit voltage nominal.

Also, the open circuit voltage which set the voltage at which the cell current is zero in the perfect case is slightly equal to [10-12]:

$$
V_{C O}=V_{T^{\prime}} \ln \left(\frac{I_{E H}}{I_{n}}+1\right)
$$

The cell temperature depends on the irradiance, the ambient temperature and the wind speed according to $[15,16]$

$$
T^{\prime}=a_{0}+a_{1} \cdot 4+a_{2} \cdot F_{c e}+a_{32} \cdot k_{5}+T_{v e f}^{\prime}+273,15
$$

where $a_{0} a_{1} a_{2} \quad a_{3}$ are constants equal to $3.12,0.25,0.899$ and -1.3 , respectively. In the equation, $\mathrm{T}$ is in ${ }^{\circ} \mathrm{K}, \Psi$ in $\mathrm{W} / \mathrm{m}^{2}$, Ta in ${ }^{\circ} \mathrm{C}$ and $\mathrm{WS}$ in $\mathrm{m} / \mathrm{s}$.

\section{RESULTS AND DISCUSSION}

The measures are achieved at Niamey (Abdou Moumouni University). Globally, experimental the task consisted of traducing the relationship between observed measures and issued model (e.g. Fig. 2.). It is composed of a photovoltaic module whose characteristics are detailed in the TABLE I and different sensors (anemometer, solar meter, thermometer, Hall Effect sensor, etc.) which are used to measure in real time the wind speed, the irradiance, the temperature and outputs of the PV module such as the voltage, the current (I) and the power (P). 


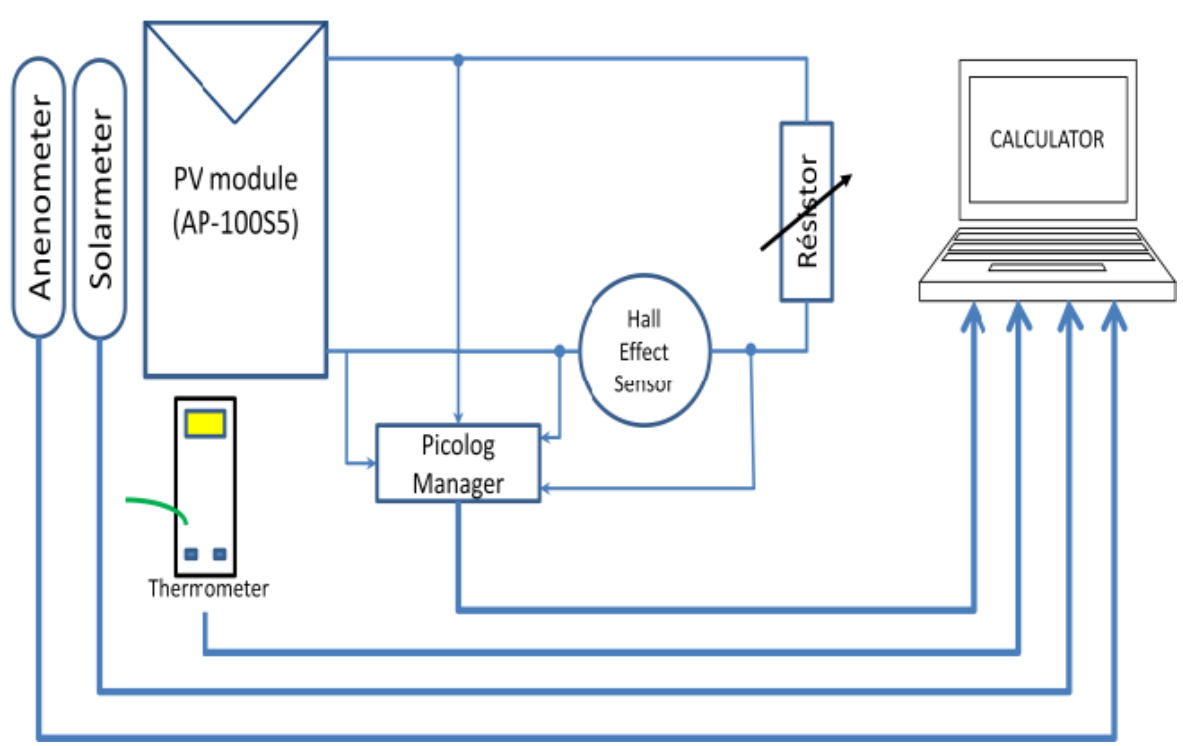

Fig. 2. Experimental bench

Table 1. Electrical and geographical characteristics pv module

\begin{tabular}{ll}
\hline Maximun power (Pm) & $70 \mathrm{~W}$ \\
Voltage at Pm (Vm) & $15,5 \mathrm{~V}$ \\
Current at Pm (Im) & $4,5 \mathrm{~A}$ \\
Open-circuit voltage (Voc) & $21,8 \mathrm{~V}$ \\
Short-circuit current (Isc) & $5,05 \mathrm{~A}$ \\
NOCT (Air $25^{\circ} \mathrm{C}$; sun $1 \mathrm{~kW} / \mathrm{m}^{2}$; wind $\left.1 \mathrm{~m} / \mathrm{s}\right)$ & $47 \pm 2^{\circ} \mathrm{C}$ \\
Temperature coefficient of Isc & $(0,065 \pm 0,015) \% /{ }^{\circ} \mathrm{C}$ \\
Temperature coefficient of Voc & $-(80 \pm 10) \mathrm{mV} /{ }^{\circ} \mathrm{C}$ \\
Temperature coefficient of power & $-(0,5 \pm 0,05) \% /{ }^{\circ} \mathrm{C}$ \\
Tolerance & \pm 3 \\
Solar Cell & 72 cells \\
Connected cell number in series & 36 \\
Connected parallel strings & 2 \\
Latitude (Niamey/Niger) & $13^{\circ} 311^{\prime} 01 "$ North \\
Longitude (Niamey/Niger & $2^{\circ} 06^{\prime \prime} 00 "$ East \\
Slant of PV module & 16 degrees South \\
\hline
\end{tabular}

For validation experiments we have considered a processing chain based on a single photovoltaic system with three following climatic parameters (irradiation, temperature and wind power). It has been obtained considering interpolation technique applied on measured data points corresponding to the possible two operating voltage outputs such as the current and power keys. Note that the estimated mean squared error rate of the compared current is 0.0069539 for $300 \mathrm{~W} / \mathrm{m}^{2}, 29{ }^{\circ} \mathrm{C}$ and $5 \mathrm{~m} / \mathrm{s}$. Moreover, this method gives correlation coefficients varying for the three mentioned climatic conditions between 97 and $99 \%$ (e.g. Fig. 3.) [16] 

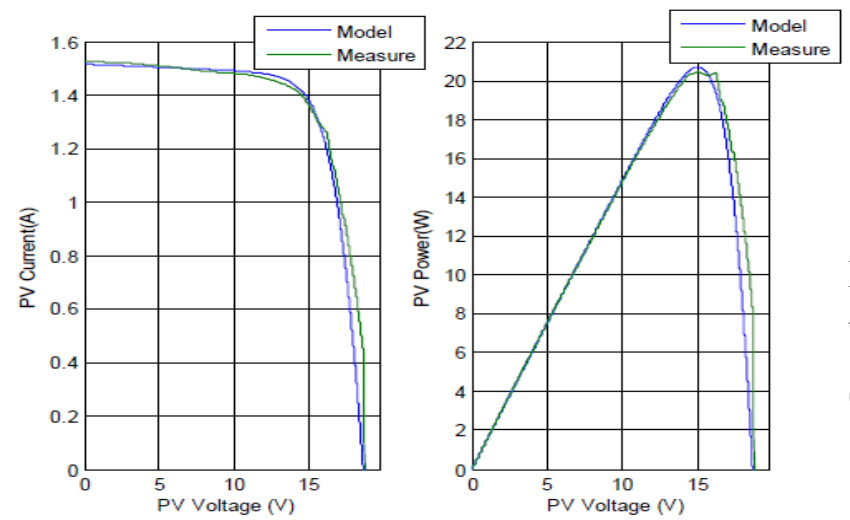

Fig. 4. Electrical

characteristics varying temperature -constant irradiance $\left(1000 \mathrm{~W} / \mathrm{m}^{2}\right)$ and wind speed $(1 \mathrm{~m} / \mathrm{s})$

The main parameters that affect the output current, power and voltage of the modeled panel have been considered. These are the solar irradiation, the wind speed and the temperature at the site. Note that if the temperature of the panel decreases, the output voltage increases for constant irradiation and wind speed. For instance (e.g. Fig. 4.), the photocurrent increases almost of $0.0005 \mathrm{~A} /{ }^{\circ} \mathrm{C}$, leading to a reduction of the open circuit voltage of the order of $0.0685 \mathrm{~V} /{ }^{\circ} \mathrm{C}$. This causes a reduction of the power of $0.3772 \mathrm{~W} /{ }^{\circ} \mathrm{C}$ for a change of $0.56 \%$. Figure 5 shows that the $\mathrm{I}-\mathrm{V}$ and $\mathrm{P}-\mathrm{V}$ output characteristics of a PV module depend on the irradiance fluctuation at constant temperature and wind speed. The PV output current and power vary with insulation conditions while the voltage output increases.

When the wind speed increases, the photocurrent decreases nearly of 6.10-4A / (m/s) (e.g. Fig. 6). This causes an increase in the open circuit voltage. This growth is in the order of $99 \mathrm{mV} /(\mathrm{m} / \mathrm{s})$ and results in a raise in the power of $0.5501 \mathrm{~W} /(\mathrm{m} / \mathrm{s})$, corresponding to a variation of $0.82 \%$. This shows that the ventilation (natural or forced) of PV modules improves the productivity, because the performance is more important at lower operating temperatures. In fact, it plays the rule of regulator cooling cells.

The performance of a photovoltaic cell is even more degraded than Rs is large. Figure 7 shows the influence of the series resistance of the electrical characteristics. This is reflected by a falling in the slope of the I-V and P-V curves in the area where the panel will operate as a source of voltage.
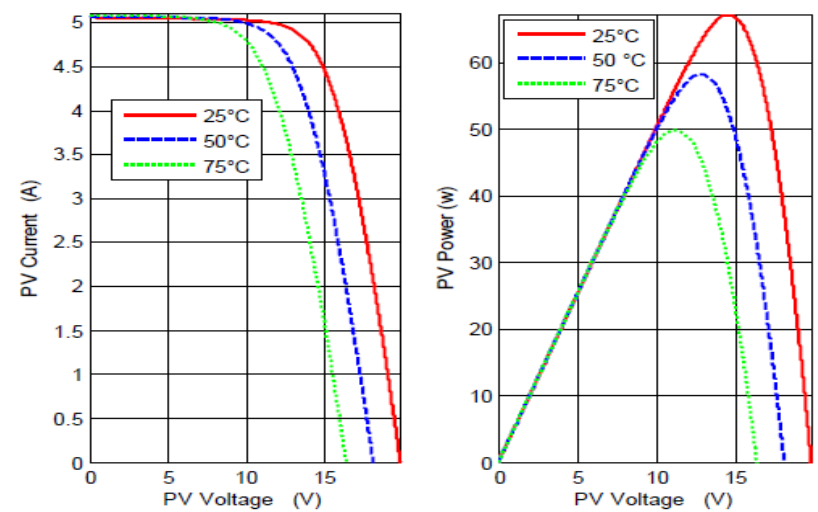

Fig. 4. Electrical characteristics varying temperature -constant irradiance $\left(1000 \mathrm{~W} / \mathrm{m}^{2}\right)$ and wind speed $(1 \mathrm{~m} / \mathrm{s})$ 

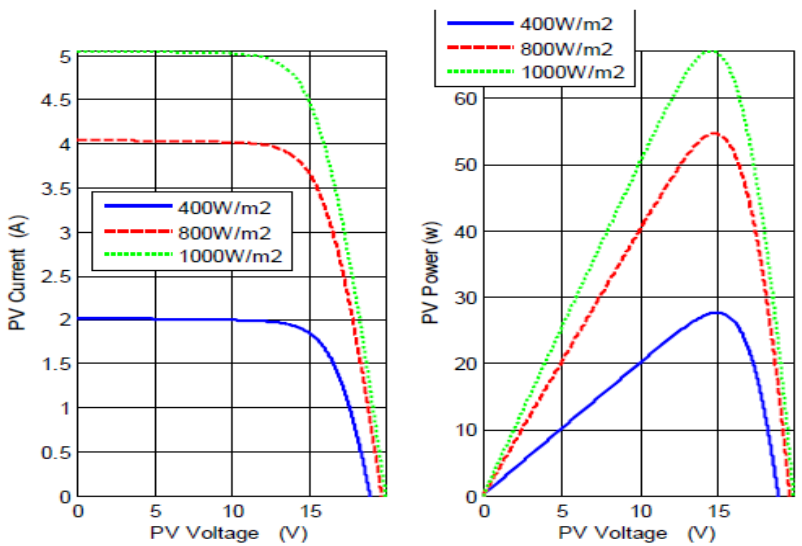

Fig. 5. Electrical characteristics of $\mathrm{PV}$ module varying irradiance-constant temperature $\left(25^{\circ} \mathrm{C}\right)$ and wind speed $(1 \mathrm{~m} / \mathrm{s})$.
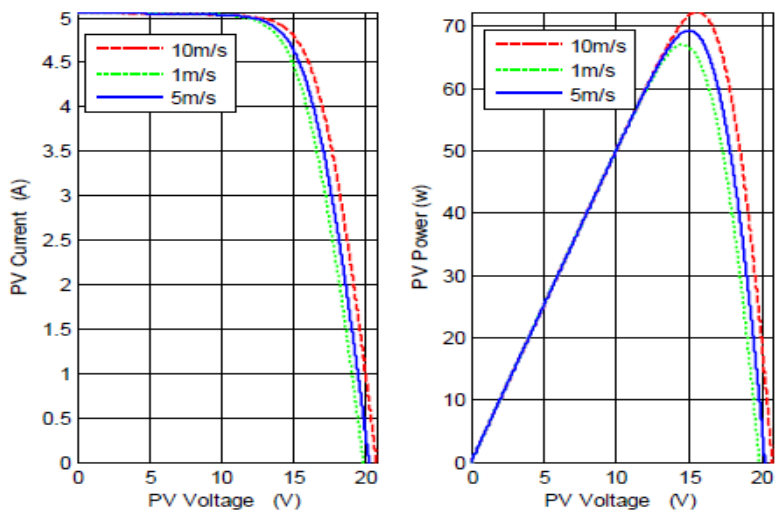

Fig. 6. Electrical characteristics of PV module -varying wind speed-constant irradiance $\left(1000 \mathrm{~W} / \mathrm{m}^{2}\right)$ and temperature $\left(25^{\circ} \mathrm{C}\right)$
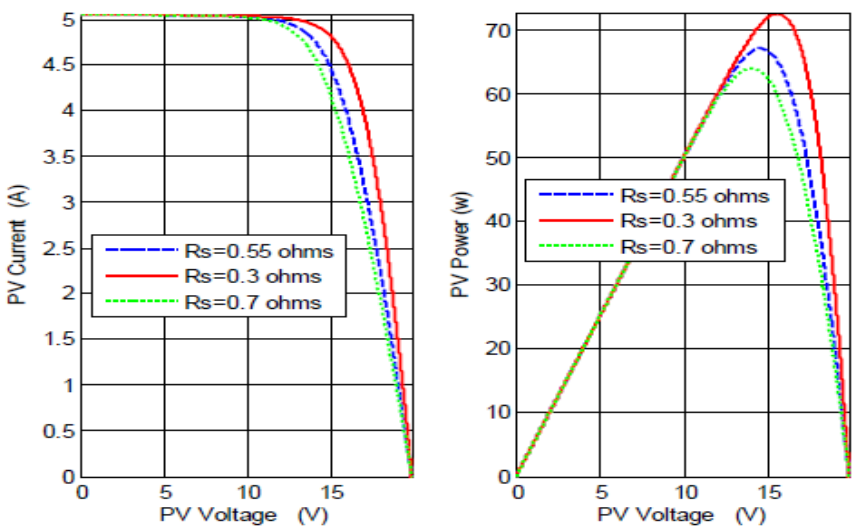

Fig. 7. Electrical characteristics-varying Resistance series- NOCT $\left(25^{\circ} \mathrm{C}, 1000 \mathrm{~W} / \mathrm{m}^{2}, 1 \mathrm{~m} / \mathrm{s}\right)$ 


\section{CONCLUSION}

The performances of a photovoltaic generator are strongly influenced by climatic conditions of the environment, especially solar radiation, temperature and wind speed. In this study, we used the empirical model with a diode to simulate the operation of the panel at different conditions and the model is validated with experimental data. The main interest was to show that taking into account the wind power parameter of the PV module is important so as to improve the electrical characteristics.

\section{References}

[1] T. MRABTI, M. El OUARIACHI, K. KASSMI, F. OLIVIE, F. BAGUI, 'Improving the operation of photovoltaic systems in response to sudden changes of weather and load ', Journal of Renewable Energy, Vol. 11 No. 1, pp . 107-117 , 2008.

[2] L. LU, 'Investigation on Characteristics and Application of Hybrid Solar/Wind Power Generation Systems', PhD Thesis, theHong Kong Polytechnic University, 2004.

[3] L. LU, H. X. YANG, 'A Study on Simulation of the Power Output and Practical Models for Building Integrated Photovoltaic Systems’, ASME Journal of Solar Energy Engineering, Vol. 126, N³, pp. 1-7, 2004.

[4] S. DIAF, M. BELHAMEL, M. HADDADI, A. LOUCHE, 'A Methodology for Optimal Sizing of Autonomous Hybrid PV/Wind System’, Energy Policy, Vol. 35, Nº11, pp. 5708 5718, 2007.

[5] E. LORENZO, 'Solar Electricity: Engineering of PhotovoltaicSystem', Progensa, Sevilla, 1994.

[6] T. MARKVART, 'Solar Electricity', John Wiley \& Sons, Chichester, 1994.

[7] A. GOETSBERGER, V. U. HOFFMANN, 'Photovoltaic Solar Energy Generation', Springer, Berlin, 2005.

[8] B. ALSAYID, J. JALLAD, 'Modeling and Simulation of Photovoltaic Cells/Modules/Arrays', International Journal of Research and Reviews in Computer Science (IJRRCS), Vol. 2, No. 6, ISSN: 2079-2557C Science Academy Publisher, www.sciacademypublisher.com, United Kingdom, 2011.

[9] S. RUSTEMLI, F. DINCER, 'Modeling of Photovoltaic Panel and Examining Effect of Temperature in Matlab/Simulink', ELECTRONICS AND ELECTRICAL ENGINEERING, ISSN 1392-1215, No.3 (109), 2011.

[10] W. De SOTO, S. A. KLEIN, W. A. BECKMAN, 'Improvement and Validation of a Model for Photovoltaic Array Performance’, Solar Energy, Vol. 80, N¹, pp.78 - 88, 2006.

[11] V. BADESCU, 'Single Optimization Procedure for Silicon-Based Solar Cell Interconnection in a Series-Parallel PV Module', Energy Conversion and Management, Vol. 47, ํ9-10, pp. 1146-1158, 2006.

[12] A. OULD MOHAMED YAHYA, A. OULD MAHMOUD, I. YOUM, 'Study and modeling of a photovoltaic generator', Journal of Renewable Energy, Vol. 11 No 3 , pp . 473-483, 2008.

[13] H. R. KAMATH, R. S. AITHAL, P. K. Singh Ashis Kumar SINHA and A.R. DANAK, 'Modeling of Photovoltaic Array and Maximum Power Point Tracking using ANN', http://journal.esrgroups.org/jes/papers/4_3_4.pdf., Vol. 4, N³, 2008.

[14] A. ZAATRI, S. BELHOUR, ' Reconstitution of the characteristic I - V and determining the power of a photovoltaic system ', Journal of Renewable Energy, Vol. 12 No. 4, pp . 563$574,2009$.

[15] ROSS, R. G. Jnr. and M. I. SMOKLER, (1986), 'Flat-Plate Solar Array Project Final Report', Volume I: Engineering Sciences and Reliability, Jet Propulsion Laboratory Publication 86-31", 1986.

[16] F. NDIAYE, M. SENE, A. MAIGA, M. BEYE, 'Modelling of polyccrytalline photovoltaic module based on climatic conditions in Niger', Unpublished 